\title{
Cell Count
}

National Cancer Institute

\section{Source}

National Cancer Institute. Cell Count. NCI Thesaurus. Code C48938.

A procedure to determine the number of cells in a sample. Also used to mean the result of such a procedure. 